\title{
Introduction to European family law volume I: The impact of institutions and organisations on European family law
}

\section{Jens M. Scherpe}

This volume looks at the impact that institutions and organisations have had and continue to have on European family law. In many ways the chapters in this volume provide the easiest explanation as to why European family law exists. While there is no European body that could actually legislate definitively on family law - even the European Union has no such mandate - there are still some obvious institutions that have an impact on European family law. Essentially these can be divided into two groups, namely those that have a direct impact and those that have an indirect impact.

The first institution undoubtedly to have a direct impact is the European Court of Human Rights, which is discussed by Dagmar Coester-Waltjen in Chapter 2 of this volume (and the fourth volume of the book set, 'The Present and Future of European Family Law', esp. 2.1.1). While the decisions of the Court nominally of course only concern the Contracting State involved in the proceedings, they nevertheless establish 'minimum standards' for - often very specific - areas of law or issues. Pertinent examples of this include Marckx v. Belgium, ${ }^{1}$ Goodwin v. United Kingdom, ${ }^{2}$ Schalk and Kopf v. Austria ${ }^{3}$ and Vallianatos v. Greece, ${ }^{4}$ all of which are discussed in detail both in this volume and the fourth volume of the book set ('The Present and Future of European Family Law', esp. 2.1.1). Therefore it has been said, quite rightly, that these decisions provide a floor upon which, in the future, all of the States

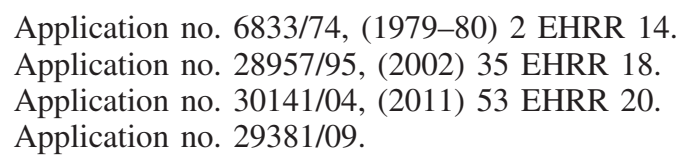

Application no. 6833/74, (1979-80) 2 EHRR 14.

Application no. 28957/95, (2002) 35 EHRR 18.

Application no. 30141/04, (2011) 53 EHRR 20.

Application no. 29381/09. 
must stand. ${ }^{5}$ This 'floor' then becomes the foundation of European family law, as Contracting States must not fall below what is required by the decision and thus the Convention. Therefore the decisions have considerable impact on law reform as well as on the interpretation of national statutes, and they 'Europeanise' the national laws across jurisdictions. At the same time the minimum standard thus set becomes a part of the common European family law. Because of the way in which this European family law comes about, it of course is not a coherent set of rules, but rather a disjointed collection of bits and pieces. But it cannot be denied that these bits and pieces form the gametes of a common European family law. ${ }^{6}$

The same, although to a lesser extent, is true for the other big institution, the European Union, and the Court of Justice of the European Union; and their impact is discussed by Geert De Baere and Kathleen Gutman (in Chapter 1 of this volume) as well as Dieter Martiny both in Chapter 7 of this volume and also in the fourth volume of the book set ('The Present and Future of European Family Law', esp. 2.1.2). Despite there not being an express family law competence, the existing competences of the European Union regarding issues of non-discrimination, Union citizenship and the free movement of workers, as well as those regarding private international law have (arguably often deliberate) spill-over effects into substantive family law. Decisions of the European Court of Justice such as Konstantinidis, ${ }^{7}$ Garcia Avello, ${ }^{8}$ Grunkin and Paul, ${ }^{9}$ and Maruko $^{10}$ are examples of such an impact. Again, by mandating certain minimum standards these institutions create pockets of European family law.

The institutions that potentially have an indirect impact on European family law can be identified easily and are addressed in the following

5 Nick Wikeley, 'Same Sex Couples, Family Life and Child Support' (2006) 122 Law Quarterly Review 542 at 544.

6 Cf. Jens M. Scherpe, 'The Gametes of a European Family Law', [2008] International Family Law Journal 98-101.

7 Christos Konstantinidis v. Stadt Altensteig - Standesamt and Landratsamt Calw - Ordnungsamt (Case C-168/91) [1993] ECR I-1191 = [1993] Common Market Law Review 401.

8 Garcia Avello v. Belgian State (Case C-148/02) [2003] ECR I-11613 = [2003] All ER (D) 38.

9 Stefan Grunkin and Dorothee Regina Paul v. Standesamt Niebüll (Case C-353/06) [2008] ECR I-7639 = [2008] All ER (D) 115.

10 Tadao Maruko v. Versorgungswerk der deutschen Bühnen (Case C-267/06) [2008] ECR I-1757 = [2008] All ER (EC) 97. 
chapters in this volume: ${ }^{11}$ the Hague Conference (Hannah Baker and Maja Groff); the Council of Europe (Nigel Lowe); the International Commission on Civil Status (Walter Pintens) and the Commission on European Family Law (CEFL) (Katharina Boele-Woelki). But the particulars of the impact are more difficult to show; in contrast with the institutions mentioned above, the impact is indirect in the sense that there are the national legislatures and courts who actually bring about the changes in the law. And these legislatures are increasingly aware that they are operating in a European environment and are creating laws accordingly; and courts are adjudicating with European Union Law and the European Convention on Human Rights in mind. These law reforms and decisions can be - and often are - inspired by the work of these institutions and indeed the developments within other European and non-European jurisdictions (on which see the second volume of the book set, 'European Family Law Volume II: The Changing Concept of 'Family' and Challenges for Domestic Family Law'). But unless this influence is made obvious by express reference to these institutions, it is hard to claim with certainty that an impact has actually occurred. We can identify however several clear examples of such indirect impact:

- The 2008 Portuguese laws on divorce and parental authority and the Czech law on parental responsibilities both rely heavily on the CEFL Principles and some of the provisions are even textually identical to the Principles. ${ }^{12}$

- The regulation of parental rights and obligations in 2005 in Slovakia was based on the Council of Europe Recommendation No R (84) 4 of the Committee of Ministers to Member States on Parental Responsibilities. ${ }^{13}$

- The European Commission's Proposal for a Regulation of the European Parliament and of the Council, on promoting the free

11 And the fourth volume of the book set ('The Present and Future of European Family Law', esp. 2.2).

12 Cf. Guilherme De Oliveira 'Changes Going on in Portuguese Family Law', Zeitschrift für das gesamte Familienrecht 2008, 1712-1714; Zdeňka Králíčková, 'New Family Law in the Czech Republic', International Survey of Family Law 2014 (Jordan Publishing Bristol 2014), 71-95. For these and further examples see Boele-Woelki, in this volume, pp. 209-260.

13 Cf. Gabriela Kubíčková, 'The changing concept of 'family' and challenges for family law in the Slovak Republic' in Jens M. Scherpe (ed.), European Family Law Volume II: The Changing Concept of 'Family' and Challenges for Domestic Family Law, p. 252; on the Recommendation see Nigel Lowe, in this volume, pp. 95-123. 
movement of citizens and businesses by simplifying the acceptance of certain public documents in the European Union and amending Regulation (EU) No 1024/2012 14 was inspired by Convention No. 16 of the International Commission on Civil Status of 8 September 1976 on the issuing of multilingual extracts from civil-status records concerning birth, marriage or death. ${ }^{15}$

Especially the academic initiative of the Commission on European Family Law (CEFL) which, based on in-depth comparative studies is drafting 'Principles of European Family Law', appears to be exercising an increasing influence. National legislatures have started to consult these Principles when thinking about family law reforms, and in some sense these Principles are slowly but surely becoming the yardstick against which national laws are measured.

The final chapter of the first volume then deals with the impact of religion on European family law. As said in the general introduction to the book set, the Christian faith is often seen as a 'basis' or at least a unifying factor of Europe and thus potentially, by extension, of European family law. But given that there exist very significant differences between the various Christian faith groups in Europe (and beyond), and that in addition many European citizens are not of the Christian faith to begin with and most jurisdictions are formally secular, at least in the contemporary day and age that the Christian faith is a common factor for the current family law may be a questionable assumption. Certain common historical roots, however, cannot be denied, and there indeed appears to be a resurgence of religious themes in certain debates (for example, on the nature of marriage). Therefore it was apt to include a chapter on religion in the first volume of the book set.

Together the contributions in this volume show not only that there is a European family law, but also that this European family law derives, directly or indirectly, from certain institutions - and this book thus depicts and discusses what can be called 'Institutional European Family Law'. ${ }^{16}$

$14 \operatorname{COM}(2013) 228$ final.

15 Cf. Walter Pintens, in this volume, pp. 124-142.

16 Which is analysed further in the fourth volume of the book set, 'The Present and Future of European Family Law'. 